\title{
Photocatalytic Antibacterial Performance of Glass Fibers Thin Film Coated with $\mathrm{N}$-Doped $\mathrm{SnO}_{2} / \mathrm{TiO}_{2}$
}

\author{
Peerawas Kongsong,' Lek Sikong, ${ }^{1}$ Sutham Niyomwas, ${ }^{2}$ and Vishnu Rachpech ${ }^{1}$ \\ ${ }^{1}$ Department of Mining and Materials Engineering, Faculty of Engineering, Prince of Songkla University, Hat Yai, \\ Songkhla 90112, Thailand \\ ${ }^{2}$ Department of Mechanical Engineering, Faculty of Engineering, Prince of Songkla University, Hat Yai, Songkhla 90112, Thailand
}

Correspondence should be addressed to Lek Sikong; lek.s@psu.ac.th

Received 19 August 2013; Accepted 30 October 2013; Published 12 February 2014

Academic Editors: C. He and G. Ouyang

Copyright (C) 2014 Peerawas Kongsong et al. This is an open access article distributed under the Creative Commons Attribution License, which permits unrestricted use, distribution, and reproduction in any medium, provided the original work is properly cited.

Both $\mathrm{N}$-doped and undoped thin films of $3 \mathrm{SnO}_{2} / \mathrm{TiO}_{2}$ composite were prepared, by sol-gel and dip-coating methods, and then calcined at $600^{\circ} \mathrm{C}$ for 2 hours. The films were characterized by FTIR, XRD, UV-Vis, SEM, and XPS, and their photocatalytic activities to degrade methylene blue in solution were determined, expecting these activities to correlate with the inactivation of bacteria, which was confirmed. The doped and undoped films were tested for activities against Gram-negative Escherichia coli (E. coli) and Salmonella typhi (S. typhi), and Gram-positive Staphylococcus aureus (S. aureus). The effects of doping on these composite films included reduced energy band gap, high crystallinity of anatase phase, and small crystallite size as well as increased photocatalytic activity and water disinfection efficiency.

\section{Introduction}

The supply of safe drinking water is an issue of concern, particularly in developing countries. Although several initiatives have been successful in supplying safe drinking water to urban populations, the extent of these efforts still falls short of the required targets for sustainable development. In developing countries, water delivery systems are plagued by leakages, illegal connections, and vandalism, and precious water resources are mismanaged. In Africa, Asia, Latin America, and the Caribbean, nearly one billion people in rural areas have no access to sufficient clean water supplies [1]. Contaminated water commonly contains dangerous pathogens, and its consumption creates serious health effects and societal problems. In the past decade, many innovative disinfection technologies were developed and adopted as alternatives to chlorine and ozone associated disinfection processes, including germicide ultraviolet (UV) radiation and photocatalytic oxidation. The traditional disinfection approaches have potential risks, such as carcinogenic byproducts (DBPs). For the alternative technologies, diverse nanophotocatalysts such as titanium dioxide $\left(\mathrm{TiO}_{2}\right)$, zinc oxide $(\mathrm{ZnO})$, cadmium sulfide (CdS), and silver nanoparticles have been widely studied and are considered promising due to their unique properties including large specific area and high reactivity [2].

$\mathrm{TiO}_{2}$ is the most commonly used semiconductor photocatalyst and the most studied of the various nanomaterials. Activated by UV-A irradiation, its photocatalytic properties have been utilized in various environmental applications to remove contaminants from both water and air. A wealth of information on $\mathrm{TiO}_{2}$ photocatalytic inactivation of bacteria has been acquired over the last 20 years. $\mathrm{TiO}_{2}$ can kill both Gram-negative and Gram-positive bacteria, although Grampositive bacteria are able to form spores and therefore are less sensitive. The exact bactericidal mechanism of reactive oxygen species (ROS) is not yet fully known, but the photocatalytic activity of $\mathrm{TiO}_{2}$ produces them, and they are extremely reactive killing or deactivating microorganisms on contact [3].

There are many techniques to improve photoactivity such as control of phase morphology, crystallite size, and reducing band gap energy. Doping $\mathrm{TiO}_{2}$ with $\mathrm{N}$ and combining it with $\mathrm{SnO}_{2}$ could improve the photochemical activity $[4,5]$. 
The aim of this work was to investigate the water disinfection efficiency of $\mathrm{N}$-doped and undoped $3 \mathrm{SnO}_{2} / \mathrm{TiO}_{2}$ composite films under UV radiation. The quantity of dopants in $\mathrm{TiO}_{2}$ films was varied. The $\mathrm{N}$-doped and undoped $3 \mathrm{SnO}_{2} / \mathrm{TiO}_{2}$ composite films were formed as coatings on glass fibers, and the photocatalytic antibacterial effects of these films against Gram-negative Escherichia coli (E. coli), Salmonella typhi (S. typhi), and Gram-positive Staphylococcus aureus (S. aureus) were assessed. The fraction of viable bacteria that survived the treatment was determined with the spread plate technique. Furthermore, photocatalytic degradation of methylene blue dye in solution was also investigated, to correlate this activity with antibacterial activity.

\section{Experimental}

2.1. Materials and Methods. The $\mathrm{TiO}_{2}$ composite films were formed on glass fibers (E-type) with two coating layers. The specific surface area of the starting glass fiber materials is $2 \mathrm{~m}^{2} \mathrm{~g}^{-1}$ [6]. The first layer was $5 \mathrm{SiO}_{2} / \mathrm{TiO}_{2}$, and this film was prepared by adding titanium (IV) isopropoxide (TTIP, 99.95\%, Fluka Sigma-Aldrich) dropwise under vigorous stirring into a mixture solution containing ethanol (99.9\%, Merck, Germany) and tetraethylorthosilicate (TEOS, 98\%, Fluka Sigma-Aldrich). The second coating layer was (optionally $\mathrm{N}$-doped) $3 \mathrm{SnO}_{2} / \mathrm{TiO}_{2}$ composite. The $\mathrm{N}$-doped $3 \mathrm{SnO}_{2} / \mathrm{TiO}_{2}$ was prepared by mixing $10 \mathrm{~mL}$ glacial acetic, $0.289 \mathrm{~g}$ ammonium carbonate, and $0.315 \mathrm{~g}$ Tin (IV) chloride pentahydrate. For the first coating layer the concentration of $\mathrm{SiO}_{2}$ was fixed at $5 \mathrm{~mol} \%$, while $\mathrm{SnO}_{2}$ doped in the second layer was fixed at $3 \mathrm{~mol} \%$. Nitrogen at $20 \mathrm{~mol} \%$ was used for doping of the $3 \mathrm{SnO}_{2} / \mathrm{TiO}_{2}$ composite films, following Qin and coworkers [7]. The $\mathrm{N}$-doped $3 \mathrm{SnO}_{2} / \mathrm{TiO}_{2}$ solutions were stirred at room temperature for $60 \mathrm{~min}$, and then $2 \mathrm{M} \mathrm{HCl}$ was added into the solution to adjust its $\mathrm{pH}$ to about 3.5.

The glass fibers were first kept at $500^{\circ} \mathrm{C}$ for $1 \mathrm{~h}$ in order to remove wax and then carefully cleaned with ethanol. A dipcoating apparatus was used to coat the fibers. The first coating with $\mathrm{SiO}_{2} / \mathrm{TiO}_{2}$ acted as a buffer layer on the glass fibers, and $\mathrm{N}$-doped $3 \mathrm{SnO}_{2} / \mathrm{TiO}_{2}$ sol was coated on the buffer layer as the second coating. A dipping speed of $1.0 \mathrm{~mm} / \mathrm{s}$ into the sols gave homogeneous coatings. The coating films were turned into gels by drying at $60^{\circ} \mathrm{C}$ for $30 \mathrm{~min}$. Then coated fibers were heated to $600^{\circ} \mathrm{C}$ at a heating rate of $10^{\circ} \mathrm{C} / \mathrm{min}$ and held for $2 \mathrm{~h}$. The coated glass fibers were cleaned by immersion in an ultrasonic bath of distilled water for $15 \mathrm{~min}$ in order to remove excess $\mathrm{TiO}_{2}$ particles. The $\mathrm{TiO}_{2}$ composite film coated glass fibers were dried at $105^{\circ} \mathrm{C}$ for $24 \mathrm{~h}$. The samples were tested immediately after they had cooled in a desiccator to ambient temperature.

2.2. Material Characterization. Surface morphology was investigated by scanning electron microscopy (SEM) and energy-dispersive X-ray spectroscopy (EDS). XPS spectra were recorded with an AXIS Ultra DLD (Kratos Analytical Ltd., UK). Phase composition was characterized with an $\mathrm{X}$-ray diffractometer (XRD) (Phillips E'pert MPD, Cu-K $\alpha$ ).
The crystallite sizes were estimated from XRD peaks using the Scherrer equation [8]:

$$
D=\frac{0.9 \lambda}{\beta \cos \theta_{\beta}},
$$

where $D$ is crystallite size, $\lambda$ is the wavelength of $\mathrm{X}$-ray radiation $(\mathrm{Cu}-\mathrm{K} \alpha=0.15406 \mathrm{~nm}), \beta$ is the angle width at half maximum height, and $\theta_{\beta}$ in degrees is the half diffraction angle of the peak centroid. The FTIR transmittance spectra of the samples were also analyzed in order to confirm hydroxyl functional groups $\left(\mathrm{TiO}_{2}-\mathrm{OH}\right.$ bonds) of the films. The band gap energies of $\mathrm{TiO}_{2}$ and $\mathrm{TiO}_{2}$ composites, in powder form, were measured by UV-Vis-NIR spectrometer with an integrating sphere attachment (Shimadzu ISR-3100 spectrophotometer) by using $\mathrm{BaSO}_{4}$ as reference. The onset absorbances were determined by the linear extrapolation of the steep part of the UV absorption toward the base line.

2.3. Photocatalytic Reaction Test. The photocatalytic activities of $\mathrm{TiO}_{2}$ and of $\mathrm{N}$-doped $3 \mathrm{SnO}_{2} / \mathrm{TiO}_{2}$ thin films on glass fibers were tested by observing the degradation of methylene blue (MB). The MB solution $(50 \mathrm{~mL})$ had $1 \times 10^{-5} \mathrm{M}$ initial concentration, and $1 \mathrm{~g}$ [8] of undoped or doped $\mathrm{TiO}_{2}$ coated glass fibers were provided excitation from a $50 \mathrm{~W}$ UV-lamp (black light) in the 310-400 nm wavelength range, set at $32 \mathrm{~cm}$ distance from the samples. The photocatalytic reaction tests were done in a dark chamber, with various UV irradiation times up to $4 \mathrm{~h}$. The remaining concentration of methylene blue was determined by UV-VIS spectrophotometer.

2.4. Photocatalytic Antibacterial Measurements. Gram-negative (E. coli and S. typhi) and Gram-positive (S. aureus) bacteria were obtained from the Microbiology Science Laboratory, Prince of Songkla University, Songkhla. The bacteria were grown aerobically in $4 \mathrm{~mL}$ of trypticase soy broth, at $37^{\circ} \mathrm{C}$ for $24 \mathrm{~h}$. Then the bacterial solution was diluted in saline solution $(0.85 \% \mathrm{NaCl})$ until the count of bacteria per milliliter of solution was in the range of 30-300. These counts were estimated by colony counter. The number of viable bacteria in a treated solution is readily quantified by spread plate technique, in which the sample is appropriately diluted and transferred to an agar plate. The grown colonies are counted, and each colony represents an initial viable bacterium in the plate culture. It is known that the initial bacterial concentration is an important factor affecting apparent antibacterial efficiency [9]. The initial bacterial concentration was set to about $10^{3} \mathrm{CFU} / \mathrm{mL}$. A $50 \mathrm{~mL}$ aliquot of bacterial suspension was treated with a $40 \mathrm{~g} / \mathrm{L}$ dose of coated glass fibers, with exposure to UV irradiation for various durations. Then, $1 \mathrm{~mL}$ of treated suspension was sampled and cultured on MacConkey agar plates (E. coli and S. typhi) or Nutrient agar plates ( $S$. aureus), by incubation at $37^{\circ} \mathrm{C}$ for $24 \mathrm{~h}$. After incubation, the colony counts were recorded as estimates of viable bacteria counts.

To assess the antimicrobial mechanisms of the $\mathrm{TiO}_{2}$ composite film coatings on glass fibers, the test fibers were dipped in $10^{3} \mathrm{CFU} / \mathrm{mL}$ bacterial solution. After incubation, bacteria attached to the coatings were fixed with $0.05 \%$ 


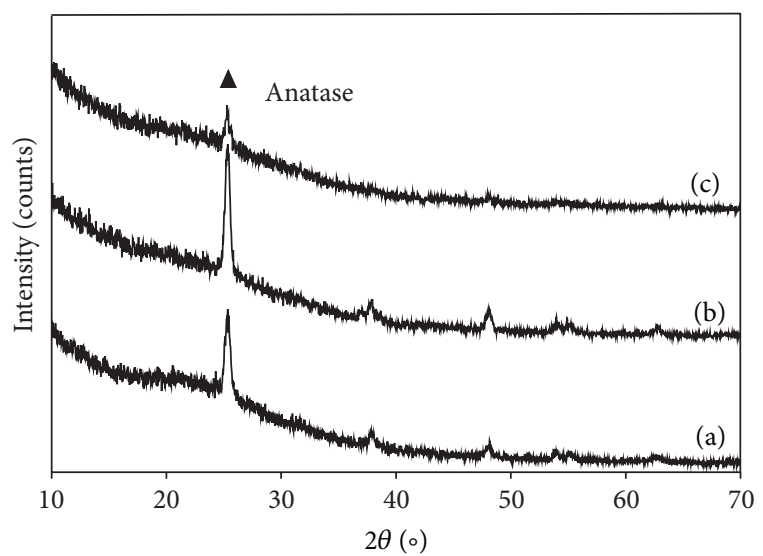

Figure 1: XRD patterns of $\mathrm{TiO}_{2}$ thin films calcined at $600^{\circ} \mathrm{C}$ : (a) $\mathrm{TiO}_{2}$, (b) $3 \mathrm{SnO}_{2} / \mathrm{TiO}_{2}$, and (c) $20 \mathrm{~N} / 3 \mathrm{SnO}_{2} / \mathrm{TiO}_{2}$.

TABLE 1: Effect of thin film type on its anatase crystallite size, energy band gap, and photocatalytic degradation of $\mathrm{MB}$ in $4 \mathrm{~h}$.

\begin{tabular}{lccc}
\hline Samples & $\begin{array}{c}\text { Crystallite } \\
\text { size }(\mathrm{nm})\end{array}$ & $\begin{array}{c}\text { Energy band } \\
\text { gap }(\mathrm{eV})\end{array}$ & $\begin{array}{c}\text { \% Degradation } \\
\text { of MB in } 4 \mathrm{~h}(\%)\end{array}$ \\
\hline $\mathrm{TiO}_{2}$ & 17.2 & 3.20 & 71.9 \\
$3 \mathrm{SnO}_{2} / \mathrm{TiO}_{2}$ & 17.2 & 3.20 & 80.3 \\
$20 \mathrm{~N} / 3 \mathrm{SnO}_{2} / \mathrm{TiO}_{2}$ & 9.8 & 3.03 & 89.5 \\
\hline
\end{tabular}

glutaraldehyde in phosphate buffer saline and dehydrated sequentially by water-alcohol solutions $(50 \%, 70 \%, 80 \%, 90 \%$, and $100 \%$ alcohol, used in this order) for $30 \mathrm{~min}$ in each solution. After dehydrating by a series of ethanol solutions, specimens were dried in a critical-point dryer. The samples were mounted on stubs and coated with gold. The cell wall characteristics were observed by SEM imaging.

\section{Results and Discussion}

3.1. XRD Results of $\mathrm{TiO}_{2}$ Thin Films. Figure 1 shows the XRD patterns of the thin films, namely, undoped $3 \mathrm{SnO}_{2} / \mathrm{TiO}_{2}$ and $20 \mathrm{~N} / 3 \mathrm{SnO}_{2} / \mathrm{TiO}_{2}$, after calcination at $600^{\circ} \mathrm{C}$ for $2 \mathrm{~h}$. By comparison with anatase and rutile ASTM cards (American Society for Testing and Materials, cards JCPDS 21-1272 and JCPDS 21-1276), the films included anatase phase, and the various types of thin films did not differ in these observations. During the high calcinations temperature, $\mathrm{TiO}_{2}$ had transformed from amorphous to anatase structure. The very broad diffraction peak at $\left(\begin{array}{lll}1 & 0 & 1\end{array}\right)$ plane $\left(2 \theta=25.3^{\circ}\right)$ was due to the small crystallite size of $\mathrm{TiO}_{2}$. The crystallite sizes calculated from Scherrer's equation are shown in Table 1. The calcined $20 \mathrm{~N} / 3 \mathrm{SnO}_{2} / \mathrm{TiO}_{2}$ composite film had the smallest $9.8 \mathrm{~nm}$ crystallites. Nitrogen doping seems to hinder phase transformation from amorphous to anatase phase, leading to a low degree of crystallinity, while $3 \mathrm{SnO}_{2} / \mathrm{TiO}_{2}$ had the highest degree of crystallinity (Figure 1). A tetragonal Bravais lattice type was evident, and the lattice constants were calculated from diffraction peaks $(a=b=0.37821 \mathrm{~nm}$ and $c=0.95402 \mathrm{~nm}$ for $3 \mathrm{SnO}_{2} / \mathrm{TiO}_{2}$, and $a=b=0.37852 \mathrm{~nm}$

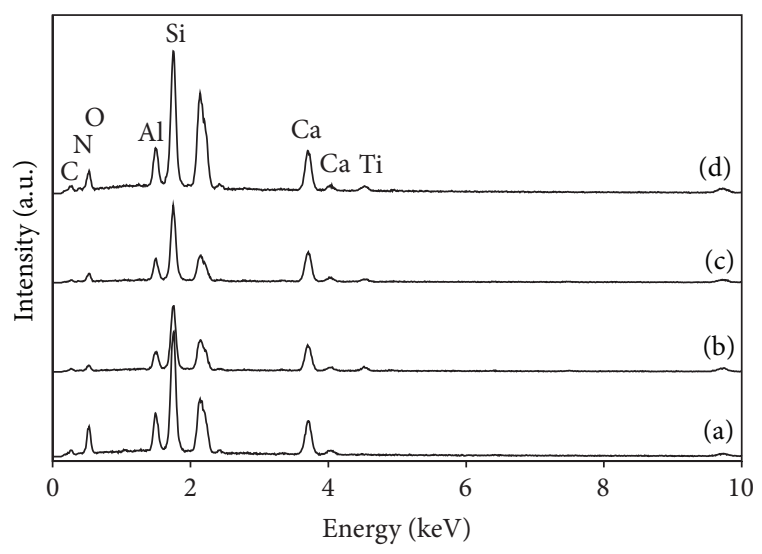

FIGURE 2: EDS spectra for (a) uncoated glass, (b) $\mathrm{TiO}_{2}$, (c) $3 \mathrm{SnO}_{2} / \mathrm{TiO}_{2}$ coating, and (d) $20 \mathrm{~N} / 3 \mathrm{SnO}_{2} / \mathrm{TiO}_{2}$ coating, all calcined at $600^{\circ} \mathrm{C}$.

and $c=0.96917 \mathrm{~nm}$ for $\left.20 \mathrm{~N} / 3 \mathrm{SnO}_{2} / \mathrm{TiO}_{2}\right)$. Compared with anatase $\mathrm{TiO}_{2}(a=b=0.37852 \mathrm{~nm}$ and $c=0.95083 \mathrm{~nm})$, the lattice parameters $a$ and $b$ of $20 \mathrm{~N} / 3 \mathrm{SnO}_{2} / \mathrm{TiO}_{2}$ were almost unchanged while $c$ had increased. Therefore, the doping had slightly distorted the crystal lattice structure, as expected [10]. Both crystallite size and degree of crystallinity are known to affect photocatalytic activity.

3.2. EDS Spectra and Morphology of Surface Thin Films. The EDS spectra taken from $\mathrm{TiO}_{2}$ and $\mathrm{TiO}_{2}$ composite films are presented in Figure 2. The elements $\mathrm{Si}, \mathrm{Al}, \mathrm{Ca}$, and $\mathrm{O}$ were mainly in the glass fiber substrates, while $\mathrm{Ti}, \mathrm{N}$, and $\mathrm{O}$ elements were in the composite films from $\mathrm{TiO}_{2}$ and $20 \mathrm{~N} / 3 \mathrm{SnO}_{2} / \mathrm{TiO}_{2}$. The peak for $\mathrm{Sn}$ is not observed, presumably because of its low dosage in the composite films. The morphologies of the coated surfaces are illustrated in Figure 3, as observed by SEM. The nucleation of anatase phase was homogeneous, and the film surface was smooth. However, some excess $\mathrm{TiO}_{2}$ had remained randomly deposited on the coatings of glass fibers. Agglomeration of nanoparticles occurred in $3 \mathrm{SnO}_{2} / \mathrm{TiO}_{2}$ films, but not in $20 \mathrm{~N} / 3 \mathrm{SnO}_{2} / \mathrm{TiO}_{2}$ films. N-doping hindered anatase crystal growth, in agreement with the XRD spectra shown in Figure 1.

3.3. FTIR Analysis. The photogenerated hydroxyl groups on titanium dioxide surface can be characterized using FTIR transmittance spectra especially the peaks at 3200$3600 \mathrm{~cm}^{-1}[11,12]$. Figure 4 shows the FTIR spectra of $\mathrm{TiO}_{2}, 3 \mathrm{SnO}_{2} / \mathrm{TiO}_{2}$, and $20 \mathrm{~N} / 3 \mathrm{SnO}_{2} / \mathrm{TiO}_{2}$ calcined at $600^{\circ} \mathrm{C}$. The bands appearing at about $3400-3468 \mathrm{~cm}^{-1}$ in $\mathrm{TiO}_{2}$, $3 \mathrm{SnO}_{2} / \mathrm{TiO}_{2}$, and $20 \mathrm{~N} / 3 \mathrm{SnO}_{2} / \mathrm{TiO}_{2}$ coatings correspond to stretching vibrations of $\mathrm{OH}$ groups linked with titanium atoms $(\mathrm{Ti}-\mathrm{OH})$. This confirms that photocatalytic reactions took place on the sample surfaces. The broad and strong peaks at $1630-1640 \mathrm{~cm}^{-1}$ are ascribed to the bending vibration of $\mathrm{OH}$ groups, of free or absorbed water $[13,14]$. The peaks at $1403 \mathrm{~cm}^{-1}$ in the spectrum of the $20 \mathrm{~N} / 3 \mathrm{SnO}_{2} / \mathrm{TiO}_{2}$ sample are assigned to the vibrations of $\mathrm{N}-\mathrm{H}$ bonds [15]. The peak 


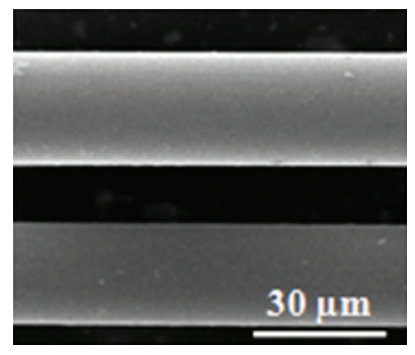

(a)

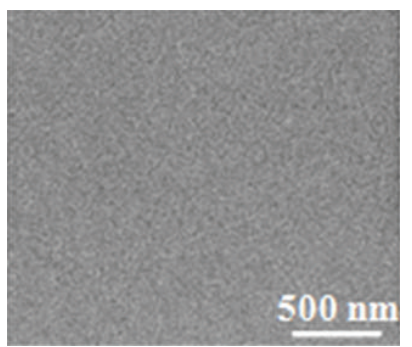

(d)

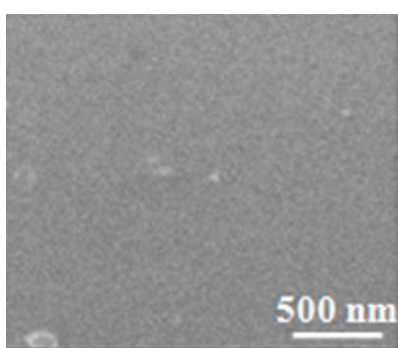

(b)

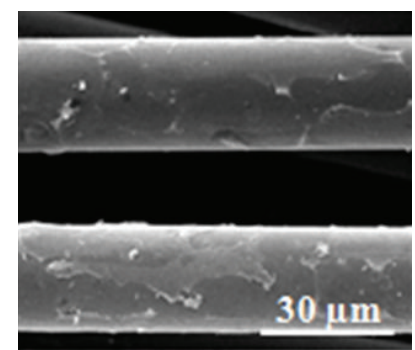

(e)

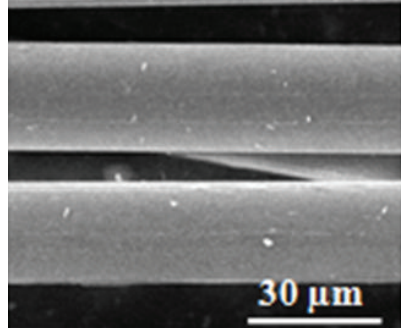

(c)

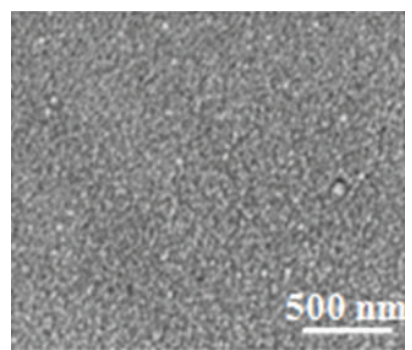

(f)

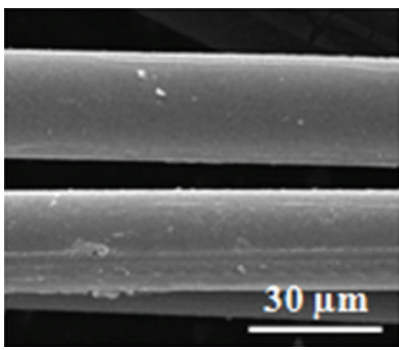

(g)

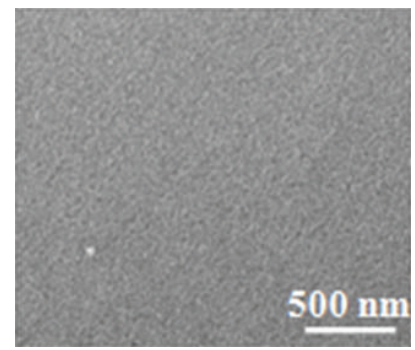

(h)

Figure 3: SEM images of glass fibers, some coated and calcined at $600^{\circ} \mathrm{C}$ : (a) uncoated 1,500x, (b) uncoated $60,000 \mathrm{x},(\mathrm{c}) \mathrm{TiO}_{2} 1,500 \mathrm{x},(\mathrm{d})$ $\mathrm{TiO}_{2} 60,000 x$, (e) $3 \mathrm{SnO}_{2} / \mathrm{TiO}_{2}$ 1,500x, (f) $3 \mathrm{SnO}_{2} / \mathrm{TiO}_{2} 60,000 \mathrm{x}$, (g) $20 \mathrm{~N} / 3 \mathrm{SnO}_{2} / \mathrm{TiO}_{2} 1,500 \mathrm{x}$, and (h) $20 \mathrm{~N} / 3 \mathrm{SnO}_{2} / \mathrm{TiO}_{2} 60,000 \mathrm{x}$.

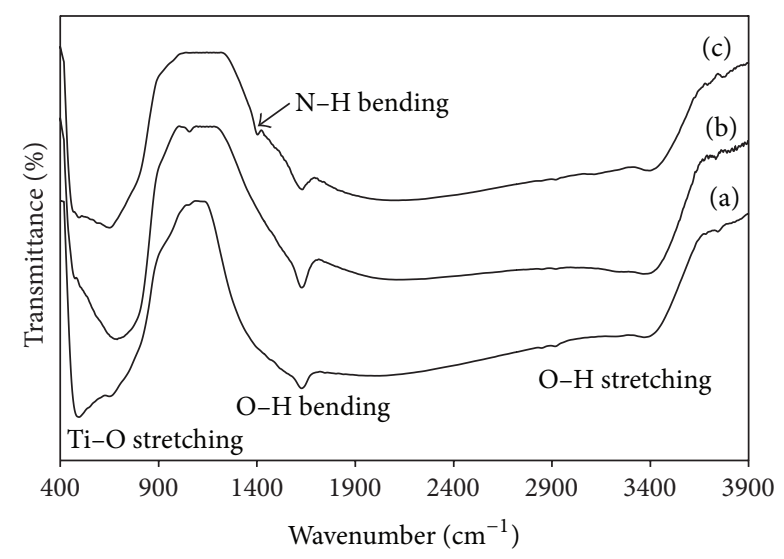

Figure 4: FTIR spectra of (a) pure $\mathrm{TiO}_{2}$, (b) $3 \mathrm{SnO}_{2} / \mathrm{TiO}_{2}$, and (c) $20 \mathrm{~N} / 3 \mathrm{SnO}_{2} / \mathrm{TiO}_{2}$ powders calcined at $600^{\circ} \mathrm{C}$.

at $600 \mathrm{~cm}^{-1}$ is ascribed to absorption bands of $\mathrm{Ti}-\mathrm{O}$ and $\mathrm{O}-\mathrm{Ti}-\mathrm{O}$, related to flexion vibration $[16]$.

3.4. Energy Gap Measurement. The photon energy versus curve of pure $\mathrm{TiO}_{2}, 3 \mathrm{SnO}_{2} / \mathrm{TiO}_{2}$, and $20 \mathrm{~N} / 3 \mathrm{SnO}_{2} / \mathrm{TiO}_{2}$ are shown in Figure 5. The absorption edge energies were determined from the following relation:

$$
E_{g}=\frac{1239.8}{\lambda}
$$

where $E_{g}(\mathrm{eV})$ is the band gap energy of the sample and $\lambda$ $(\mathrm{nm})$ is the onset wavelength of the spectrum. The dopants affected the UV-Vis spectra by inhibiting recombination of electron-hole pairs, especially in the case of $\mathrm{N}$-doping. The band gap energy of $\mathrm{N}$-doped $\mathrm{TiO}_{2}$ is shifted by $0.17 \mathrm{eV}$ from the $3.20 \mathrm{eV}$ of pure $\mathrm{TiO}_{2}$ (Table 1), and $3 \mathrm{SnO}_{2} / \mathrm{TiO}_{2}$ showed a smaller shift to $3.20 \mathrm{eV}$. These effects suggest a strategy for mediating photocatalysis through atomic-level doping of nanocatalysts. It can be seen that the absorption wavelength of $20 \mathrm{~N} / 3 \mathrm{SnO}_{2} / \mathrm{TiO}_{2}$ photocatalyst is extended towards visible light $(\lambda=409.2 \mathrm{~nm})$ relative to other varyingly doped samples [16] or pure $\mathrm{TiO}_{2}$. The nitrogen doping hinders the growth of anatase phase (Figure 1) or it can reduce the crystallite size of $\mathrm{TiO}_{2}$ composite films to be about $10 \mathrm{~nm}$ (Table 1), leading to a quantum confinement effect of nanocrystals and the highest photocatalytic activity. 


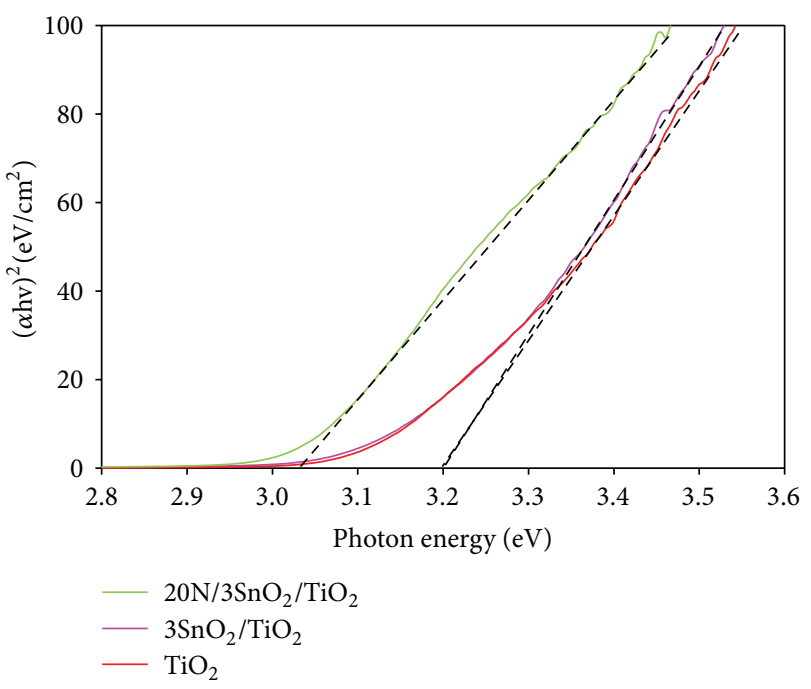

FIGURE 5: The photon energy versus $(\alpha \mathrm{hv})^{2}$ curve of representative pure $\mathrm{TiO}_{2}, 3 \mathrm{SnO}_{2} / \mathrm{TiO}_{2}$, and $20 \mathrm{~N} / 3 \mathrm{SnO}_{2} / \mathrm{TiO}_{2}$ samples calcined at $600^{\circ} \mathrm{C}$.

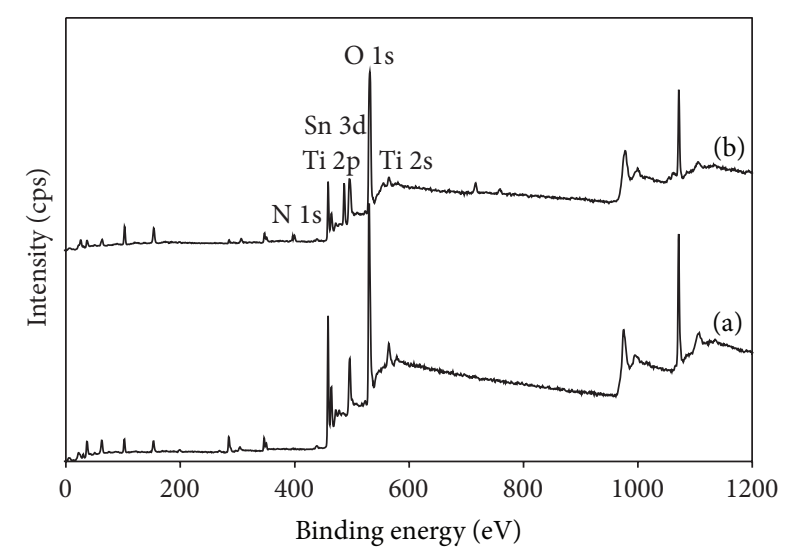

Figure 6: XPS spectra of (a) $\mathrm{TiO}_{2}$ and (b) $20 \mathrm{~N} / 3 \mathrm{SnO}_{2} / \mathrm{TiO}_{2}$ thin films, calcined at $600^{\circ} \mathrm{C}$.

3.5. XPS Analysis. Figure 6 shows the X-ray photoelectron spectroscopic (XPS) spectra of $\mathrm{TiO}_{2}$ and $20 \mathrm{~N} / 3 \mathrm{SnO}_{2} / \mathrm{TiO}_{2}$ thin films. The Ti, O, N, and Sn elements were detected in $20 \mathrm{~N} / 3 \mathrm{SnO}_{2} / \mathrm{TiO}_{2}$ thin films, in the respective percentages $7.25,61.44,1.35$, and 2.39. The XPS peaks indicate that the codoped $\mathrm{TiO}_{2}$ powders contain $\mathrm{Ti}, \mathrm{Sn}, \mathrm{O}$, and $\mathrm{N}$ elements, and the binding energies of Ti $2 \mathrm{p}, \mathrm{Sn} 3 \mathrm{~d}, \mathrm{O} 1 \mathrm{~s}$, and $\mathrm{N} 1 \mathrm{~s}$ are $458,486,531$, and $399 \mathrm{eV}$, respectively. The Sn $3 \mathrm{~d}$ peak in the spectrum of $\mathrm{Sn}-\mathrm{TiO}_{2-x}$, shown in Figure 7, demonstrates tin on the surface of $\mathrm{TiO}_{2}$. The $485.1 \mathrm{eV}$ binding energy of tin in $\mathrm{Sn}_{-}-\mathrm{TiO}_{2-x}$ is lower than the reference $486.6 \mathrm{eV}$ energy reported for Sn 3d5/2-binding [17]. To assess the chemical state of $\mathrm{N}$ in $20 \mathrm{~N} / 3 \mathrm{SnO}_{2} / \mathrm{TiO}_{2}$ thin films, a highresolution XPS spectrum of $\mathrm{N}$ 1s was measured; see Figure 8. The $\mathrm{N}$ 1s binding energy peaks were broad and asymmetric, demonstrating at least two chemical states of $\mathrm{N}$, with binding energies 397.0 and $399.6 \mathrm{eV}$. Each of these broad peaks was decomposed to three peaks, by curve fitting, indicating two

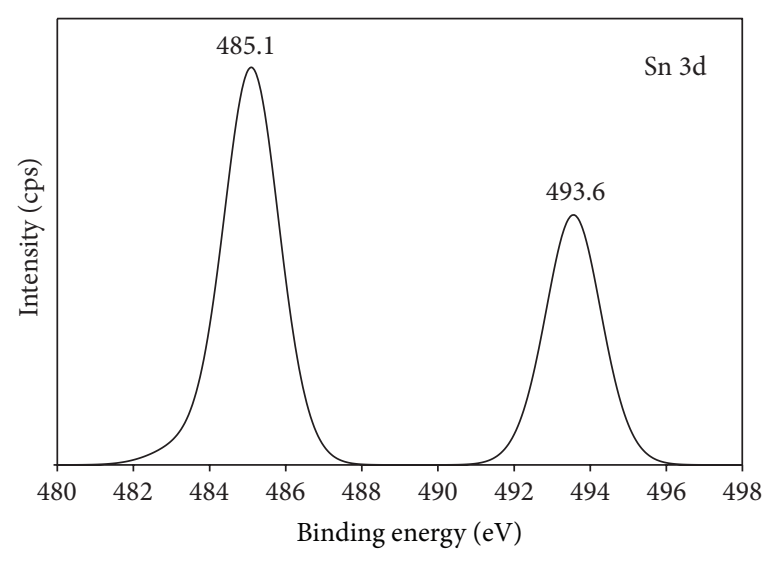

FIGURE 7: XPS spectrum of $\mathrm{Sn} 3 \mathrm{~d}$ on the surface of $20 \mathrm{~N} / 3 \mathrm{SnO}_{2} / \mathrm{TiO}_{2}$ thin film, calcined at $600^{\circ} \mathrm{C}$.

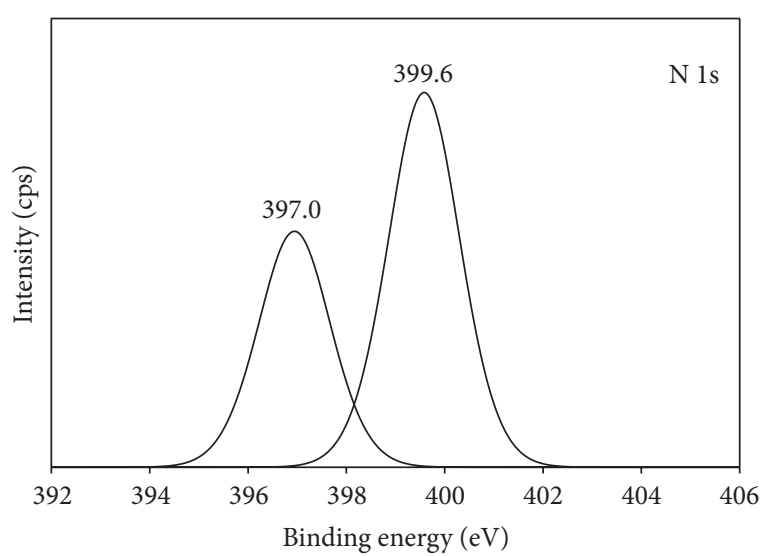

FIGURE 8: XPS spectrum of $\mathrm{N} 1 \mathrm{~s}$ on the surface of $20 \mathrm{~N} / 3 \mathrm{SnO}_{2} / \mathrm{TiO}_{2}$ thin film, calcined at $600^{\circ} \mathrm{C}$.

different states of $\mathrm{N}$. The main peak at $399.6 \mathrm{eV}$ binding energy was attributed to the $\mathrm{N}-\mathrm{Ti}-\mathrm{O}$ environment, while the peaks at $397.0 \mathrm{eV}$ were assigned to the substitutional nitrogen in the $\mathrm{Ti}-\mathrm{N}$ structure [18].

3.6. Photocatalytic Activity Test. The photocatalytic activities of $\mathrm{TiO}_{2}$ and the composite films were determined, by measuring degradation of methylene blue in solution (MB) with an initial concentration of $1 \times 10^{-5} \mathrm{M}$, under UV for various irradiation times. Figure 9 shows the fraction of the $\mathrm{MB}$ remaining versus irradiation time, which equals current concentration relative to initial concentration, $C / C_{0}$. The $3 \mathrm{SnO}_{2} / \mathrm{TiO}_{2}$ had better photocatalytic activity than pure $\mathrm{TiO}_{2}$, possibly because photogenerated electrons can accumulate in $\mathrm{SnO}_{2}$ and photogenerated holes in $\mathrm{TiO}_{2}$, with a heterojunction formed at the $\mathrm{SnO}_{2}-\mathrm{TiO}_{2}$ interface. This would lower the recombination rate of photogenerated charge carriers, giving higher quantum efficiency and better photocatalytic activity [19]. The N-doped $20 \mathrm{~N} / 3 \mathrm{SnO}_{2} / \mathrm{TiO}_{2}$ thin films had the most photoactivity (Figure 10). According to prior research, factors influencing the photoactivity of $\mathrm{TiO}_{2}$ photocatalysts include crystalline phase, grain size, 


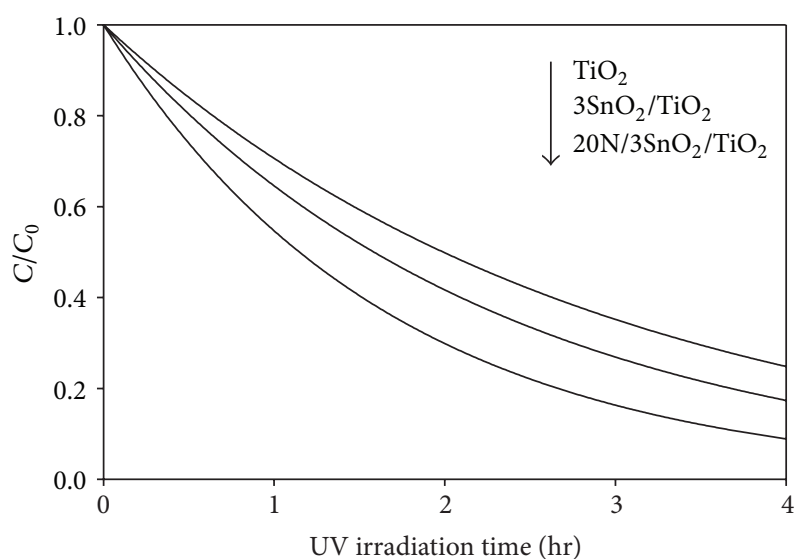

FIGURE 9: Photocatalytic degradation of MB in solution under UV excitation by various thin film coatings on glass fibers. The surface area of thin film available for reaction was held approximately constant, based on weight of glass fibers.

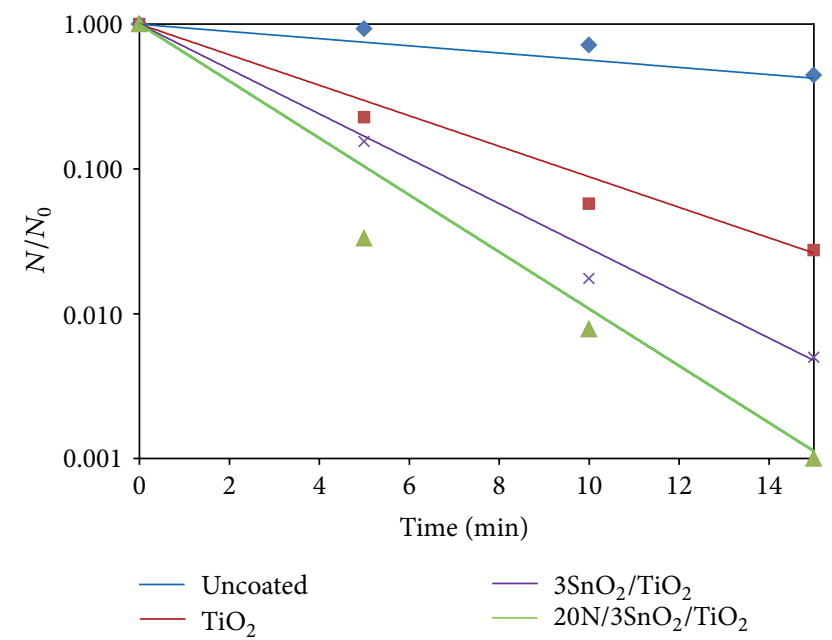

FIGURE 10: Antibacterial effects of coated glass fibers against S. typhi under UV irradiation.

specific surface area, surface morphology, and surface state (surface $\mathrm{OH}^{-}$radicals), and these factors are correlated [20, 21]. Doping $\mathrm{TiO}_{2}$ with $\mathrm{N}$ shifts its light absorption wavelength to the visible region, reduces crystallite size, and narrows its energy band gap $(3.03 \mathrm{eV})$ [22]. A well-crystallized anatase phase facilitates transfer of photo-induced vacancies from bulk to surface, for degradation of organic composites, and effectively inhibits the recombination between photogenerated electrons and holes, giving excellent photocatalytic activity. As seen in Figure 1, the $20 \mathrm{~N} / 3 \mathrm{SnO}_{2} / \mathrm{TiO}_{2}$ thin film had the smallest crystallite size, estimated to be about $9.8 \mathrm{~nm}$ (Table 1). The reaction rate constant $k$ determined is a direct quantitative indicator of photocatalytic activity (Table 2), and $k$ was highest at $0.6 \mathrm{hr}^{-1}$ for the $20 \mathrm{~N} / 3 \mathrm{SnO}_{2} / \mathrm{TiO}_{2}$ composite film, almost double that of pure $\mathrm{TiO}_{2}$.

3.7. Photocatalytic Disinfection against Bacteria. The photoinactivation of bacteria, in distilled water containing
TABLE 2: A summary of numerical fits of first-order kinetics to the degradation of MB.

\begin{tabular}{lccc}
\hline Samples & Rate equation & Rate constant $(k)\left(\mathrm{hr}^{-1}\right)$ & $R^{2}$ \\
\hline $\mathrm{TiO}_{2}$ & $C=e^{-0.34 t}$ & 0.34 & 0.952 \\
$3 \mathrm{SnO}_{2} / \mathrm{TiO}_{2}$ & $C=e^{-0.43 t}$ & 0.43 & 0.975 \\
$20 \mathrm{~N} / 3 \mathrm{SnO}_{2} / \mathrm{TiO}_{2}$ & $C=e^{-0.60 t}$ & 0.60 & 0.974 \\
\hline
\end{tabular}

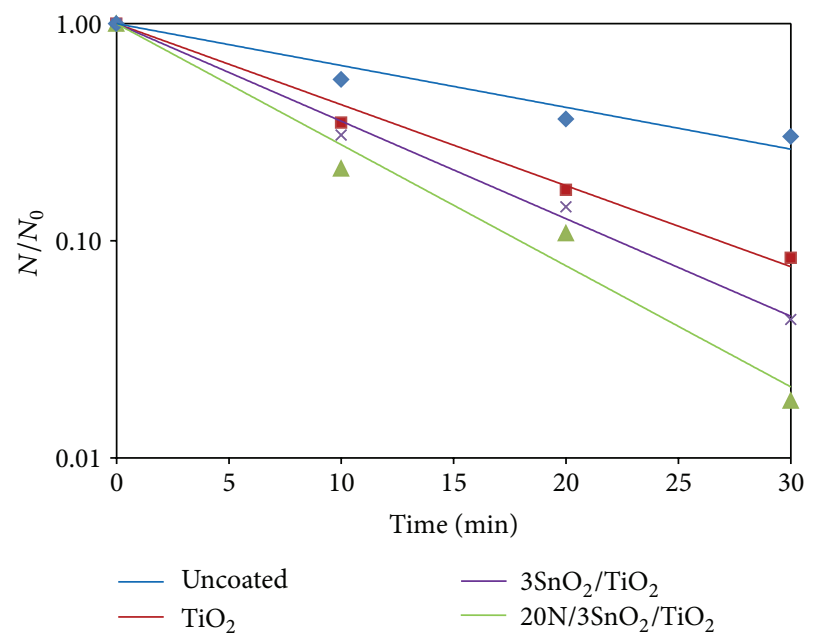

FIGURE 11: Antibacterial effects of glass fibers with various coatings against $E$. coli under UV irradiation.

the pathogen, was tested with UV excitation. The initial bacterial concentration was about $10^{3} \mathrm{CFU} / \mathrm{mL}$, and the results are shown in Figures 10-13. The survival rates of bacteria were estimated from CFU cultures that determine the number of viable cells. The survival curves in Figures 10-12 show the fraction surviving $N / N_{0}$, where $N_{0}$ is the initial and $N$ the current viable count, at a given duration of irradiation. The $20 \mathrm{~N} / 3 \mathrm{SnO}_{2} / \mathrm{TiO}_{2}$ film had the highest bactericidal activity, better than either pure $\mathrm{TiO}_{2}$ or $3 \mathrm{SnO}_{2} / \mathrm{TiO}_{2}$ with similar UV excitation, and dramatically better than UV alone. In the presence of $20 \mathrm{~N} / 3 \mathrm{SnO}_{2} / \mathrm{TiO}_{2}$, $S$. typhi was almost completely inactivated within $10 \mathrm{~min}$ and completely killed within $15 \mathrm{~min}$. In comparison with control fibers, $\mathrm{TiO}_{2}$, and $3 \mathrm{SnO}_{2} / \mathrm{TiO}_{2}$ thin films, S. typhi was killed $74 \%, 97 \%$, and $99.5 \%$, respectively, after $15 \mathrm{~min}$ UV irradiation (Figure 10). The results shown in Figure 11 for E. coli are qualitatively similar, with almost complete inactivation reached within $30 \mathrm{~min}$ and complete kill within $40 \mathrm{~min}$ in the best case, and the different film types had the same rank order as above. The rank order remained the same with $S$. aureus, which was completely killed within $60 \mathrm{~min}$ in the best case (Figure 12). Clearly the $20 \mathrm{~N} / 3 \mathrm{SnO}_{2} / \mathrm{TiO}_{2}$ film had the best antibacterial effects against each pathogen tested. The antibacterial activity of the prepared films correlates well with the photocatalytic activity, determined from degradation of methylene blue. The inactivation rate constant, $k$ of control (uncoated glass fibers under UV irradiation), $\mathrm{TiO}_{2}, 3 \mathrm{SnO}_{2} / \mathrm{TiO}_{2}$, and $20 \mathrm{~N} / 3 \mathrm{SnO}_{2} / \mathrm{TiO}_{2}$ films determined from Figures 10-12 illustrated in Table 3, is a 
TABLE 3: A summary of numerical fits of first-order kinetics to the inactivation of bacteria.

\begin{tabular}{|c|c|c|c|c|}
\hline Bacteria & Samples & Rate Equation & Rate constant $(k)\left(\mathrm{min}^{-1}\right)$ & $R^{2}$ \\
\hline \multirow{4}{*}{ S. typhi } & Uncoated & $N=e^{-0.050 t}$ & 0.050 & 0.883 \\
\hline & $\mathrm{TiO}_{2}$ & $N=e^{-0.240 t}$ & 0.240 & 0.975 \\
\hline & $3 \mathrm{SnO}_{2} / \mathrm{TiO}_{2}$ & $N=e^{-0.350 t}$ & 0.350 & 0.990 \\
\hline & $20 \mathrm{~N} / 3 \mathrm{SnO}_{2} / \mathrm{TiO}_{2}$ & $N=e^{-0.450 t}$ & 0.450 & 0.960 \\
\hline \multirow{4}{*}{ E. coli } & Uncoated & $N=e^{-0.044 t}$ & 0.044 & 0.935 \\
\hline & $\mathrm{TiO}_{2}$ & $N=e^{-0.086 t}$ & 0.086 & 0.986 \\
\hline & $3 \mathrm{SnO}_{2} / \mathrm{TiO}_{2}$ & $N=e^{-0.103 t}$ & 0.103 & 0.993 \\
\hline & $20 \mathrm{~N} / 3 \mathrm{SnO}_{2} / \mathrm{TiO}_{2}$ & $N=e^{-0.128 t}$ & 0.128 & 0.975 \\
\hline \multirow{4}{*}{ S. aureus } & Uncoated & $N=e^{-0.036 t}$ & 0.036 & 0.888 \\
\hline & $\mathrm{TiO}_{2}$ & $N=e^{-0.058 t}$ & 0.058 & 0.940 \\
\hline & $3 \mathrm{SnO}_{2} / \mathrm{TiO}_{2}$ & $N=e^{-0.070 t}$ & 0.070 & 0.944 \\
\hline & $20 \mathrm{~N} / 3 \mathrm{SnO}_{2} / \mathrm{TiO}_{2}$ & $N=e^{-0.082 t}$ & 0.082 & 0.936 \\
\hline
\end{tabular}

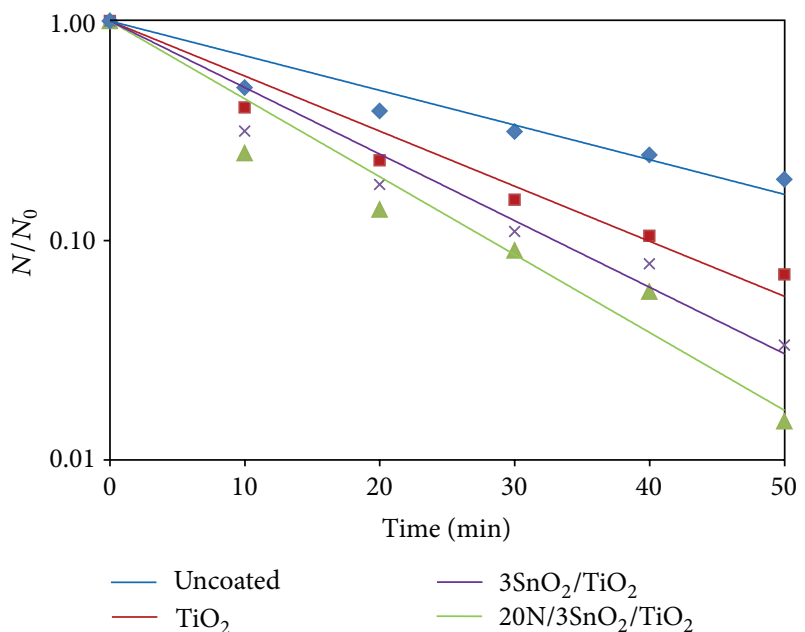

FigURE 12: Antibacterial effects of glass fibers with various coatings against $S$. aureus under UV irradiation.

direct quantitative indicator of antibacterial activity. It is seen that the $k$ value of $20 \mathrm{~N} / 3 \mathrm{SnO}_{2} / \mathrm{TiO}_{2}$ film was higher than that of other samples due to its smaller crystallite size or larger surface area. The killing rate, $k$, was the highest at $0.450 \mathrm{~min}^{-1}$ for S. typhi disinfection compared to 0.128 and $0.082 \mathrm{~min}^{-1}$ for $E$. coli and $S$. aureus, respectively. Figure 13 shows the antibacterial efficiency of $20 \mathrm{~N} / 3 \mathrm{SnO}_{2} / \mathrm{TiO}_{2}$ composite thin film under UV irradiation. This thin film has a stronger antibacterial effect on Gram-negative than Gram-positive bacteria, because Gram-positive bacteria have thick cell walls composed of multilayered peptidoglycan [23], and also E. coli has thicker cell walls than S. typhi. The bactericidal effect of $\mathrm{TiO}_{2}$ has been started from the damage of bacterial outer membranes after contact with reactive oxygen species (ROS), primarily hydroxyl radicals $\left(\mathrm{OH}^{\bullet}\right)$, which leads to phospholipid peroxidation and ultimately cell death. It has also been suggested that nanomaterials that can physically attach to a cell could be bactericidal on such contact [24].

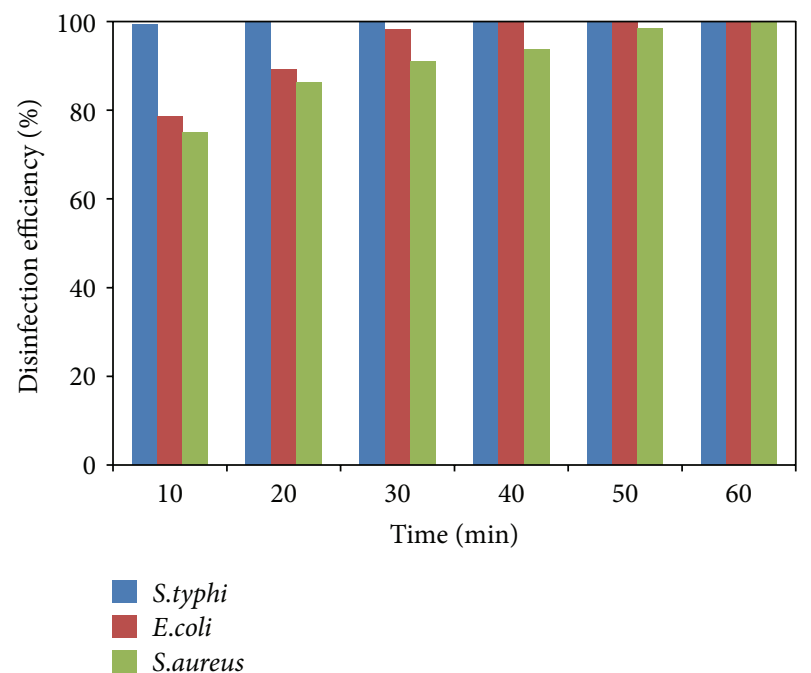

FIGURE 13: Antibacterial effects of $20 \mathrm{~N} / 3 \mathrm{SnO}_{2} / \mathrm{TiO}_{2}$ coated glass fibers against $S$. typhi, E. coli and, S. aureus under UV irradiation.

The photos in Figure 14 show bacterial cultures on agar plates, illustrative of viable counts after various treatment times with $20 \mathrm{~N} / 3 \mathrm{SnO}_{2} / \mathrm{TiO}_{2}$ under UV irradiation. The damage to cell walls of bacteria can be immediate on irradiation in the presence of $\mathrm{TiO}_{2}$ thin films, and is followed by further damage to the cell membranes [25]. SEM images of bacteria before and after treatment with $20 \mathrm{~N} / 3 \mathrm{SnO}_{2} / \mathrm{TiO}_{2}$ thin films are shown in Figures 15(a), 15(b), and 15(c) and Figures 15(d), 15(e), and 15(f), respectively. The cell walls of untreated bacteria were normal, and the number of germs was high (Figures 15(a)-15(c)). After $15 \mathrm{~min}$ of UV irradiation the cell walls and cell membranes were damaged by contact with $\mathrm{TiO}_{2}$ composite films. The mechanism of this effect is that the photo-generated hydroxyl $\left(\mathrm{OH}^{\circ}\right)$ and super oxygen $\left(\mathrm{O}_{2}^{-\bullet}\right)$ radicals react, as powerful oxidizing agents, with peptidoglycan (poly- $N$-acetylglucosamine and $N$-acetylmuramic acid) of bacterialcell wall [26]. 


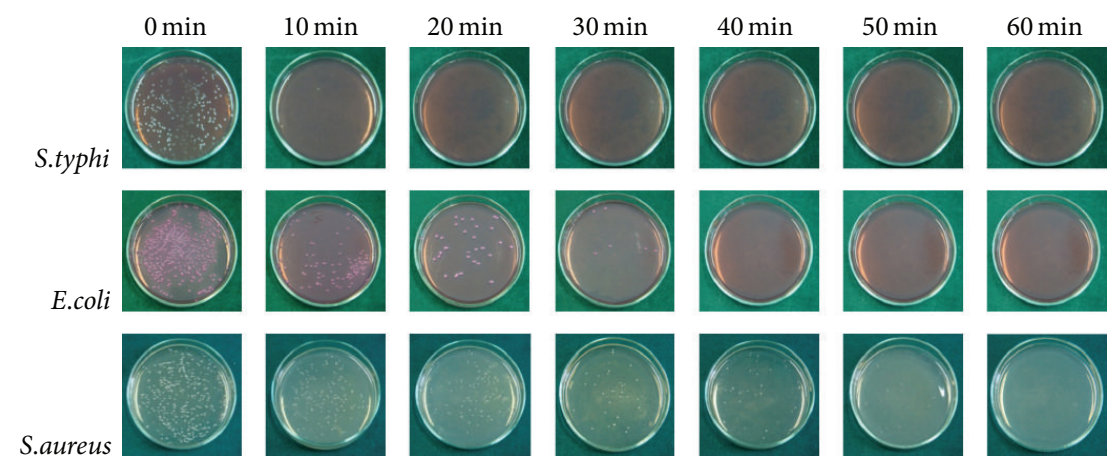

FIGURE 14: Growth of bacterial colonies on agar plates, after various treatment times. Glass fibers coated with $20 \mathrm{~N} / 3 \mathrm{SnO}_{2} / \mathrm{TiO}{ }_{2}$ were used to treat S. typhi, E. coli, and S. aureus under UV irradiation, and the number of colonies corresponds to remaining viable count of bacteria.

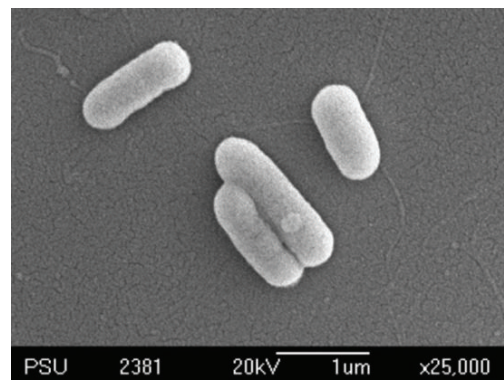

(a)

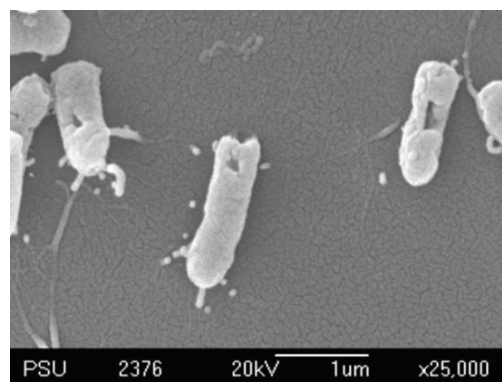

(d)

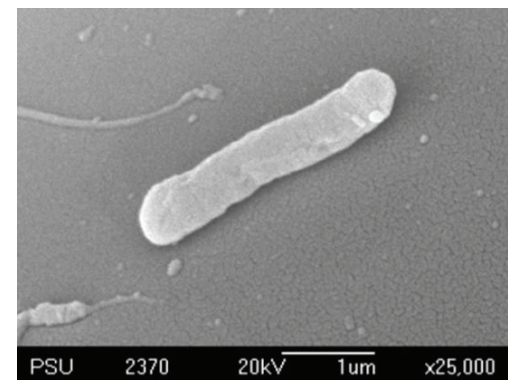

(b)

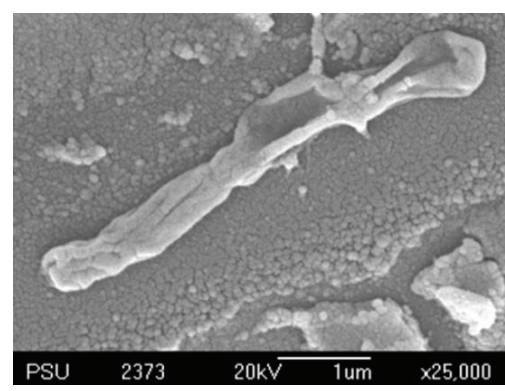

(e)

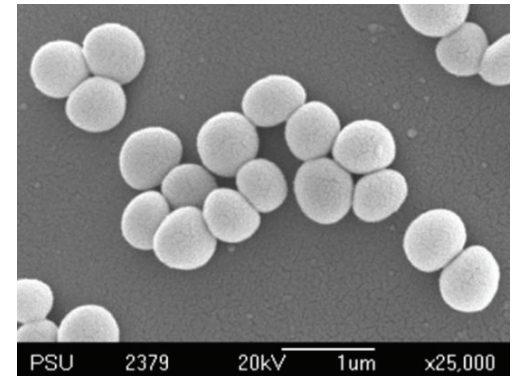

(c)

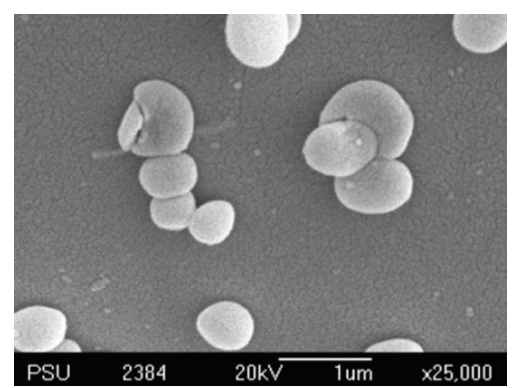

(f)

FiguRE 15: SEM images of bacteria observed on surface coated thin films: (a) untreated (S. typhi), (b) untreated (E. coli), (c) untreated (S. aureus), (d) irradiated for $15 \mathrm{~min}$ (S. typhi), (e) irradiated for $40 \mathrm{~min}$ (E. coli), and (f) irradiated for $60 \mathrm{~min}\left(\mathrm{~S}\right.$. aureus) of $20 \mathrm{~N} / 3 \mathrm{SnO}{ }_{2} / \mathrm{TiO}_{2}$ composite thin films.

\section{Conclusion}

$\mathrm{N}$-doped and undoped $3 \mathrm{SnO}_{2} / \mathrm{TiO}_{2}$ composite films were prepared as coatings on glass fibers, by sol-gel and dipcoating methods. The films were heated to $600^{\circ} \mathrm{C}$ at a rate of $10^{\circ} \mathrm{C} / \mathrm{min}$ and held for $2 \mathrm{~h}$, in order to form anatase phase. The $20 \mathrm{~N} / 3 \mathrm{SnO}_{2} / \mathrm{TiO}_{2}$ composite film had comparatively narrow band gap energy, high crystallinity of anatase phase, and small crystallite size as well as the highest photocatalytic activity of the films prepared. Its antibacterial activity under UV irradiation was superior to undoped $\mathrm{TiO}_{2}$ films, correlating well with photocatalytic activity determined from MB degradation. Antibacterial activity was experimentally established against selected bacteria of both Gram-positive and Gramnegative types, with stronger antibacterial effects against
Gram-negative type. The synthesized $20 \mathrm{~N} / 3 \mathrm{SnO}_{2} / \mathrm{TiO}_{2}$ film coated on glass fibers is antibacterial photocatalyst that will be suitable for water purification.

\section{Conflict of Interests}

The authors declare that there is no conflict of interests regarding the publication of this paper.

\section{Acknowledgments}

The authors gratefully acknowledge support by the Department of Mining and Materials Engineering, Faculty of Engineering, Prince of Songkla University and financial support 
to Peerawas Kongsong and Lek Sikong by the Thailand Research Fund through the Royal Golden Jubilee Ph.D. Program (Grant no. PHD/0169/2553). Associate Professor Dr. Seppo Karrila, from the Faculty of Science and Technology, is also acknowledged for comments and suggestions, as is the copyediting service of the Research and Development Office of PSU.

\section{References}

[1] S. Gelover, L. A. Gómez, K. Reyes, and M. Teresa Leal, "A practical demonstration of water disinfection using $\mathrm{TiO}_{2}$ films and sunlight," Water Research, vol. 40, no. 17, pp. 3274-3280, 2006.

[2] P. Gao, J. Liu, T. Zhang, D. D. Sun, and W. Ng, "Hierarchical $\mathrm{TiO}_{2} / \mathrm{CdS}$ "spindle-like" composite with high photodegradation and antibacterial capability under visiblelight irradiation," Journal of Hazardous Materials, vol. 229-230, pp. 209-216, 2012.

[3] Q. Li, S. Mahendra, D. Y. Lyon et al., "Antimicrobial nanomaterials for water disinfection and microbial control: potential applications and implications," Water Research, vol. 42, no. 18, pp. 4591-4602, 2008.

[4] N. T. Nolan, D. W. Synnott, M. K. Seery, S. J. Hinder, A. Van Wassenhoven, and S. C. Pillai, "Effect of N-doping on the photocatalytic activity of sol-gel $\mathrm{TiO}_{2}$," Journal of Hazardous Materials, vol. 211-212, pp. 88-94, 2012.

[5] L. C. Chen, F. R. Tsai, S. H. Fang, and Y. C. Ho, "Properties of sol-gel $\mathrm{SnO}_{2} / \mathrm{TiO}_{2}$ electrodes and their photoelectrocatalytic activities under UV and visible light illumination," Electrochimica Acta, vol. 54, no. 4, pp. 1304-1311, 2009.

[6] L. Kiwi-Minsker, I. Yuranov, B. Siebenhaar, and A. Renken, "Glass fiber catalysts for total oxidation of $\mathrm{CO}$ and hydrocarbons in waste gases," Catalysis Today, vol. 54, no. 1, pp. 39-46, 1999.

[7] H. L. Qin, G. B. Gu, and S. Liu, "Preparation of nitrogen-doped titania with visible-light activity and its application," Comptes Rendus Chimie, vol. 11, no. 1-2, pp. 95-100, 2008.

[8] Z. Liuxue, L. Peng, and S. Zhixing, "Photocatalysis anatase thin film coated PAN fibers prepared at low temperature," Materials Chemistry and Physics, vol. 98, no. 1, pp. 111-115, 2006.

[9] W. Zhang, Y. Chen, S. Yu, S. Chen, and Y. Yin, "Preparation and antibacterial behavior of $\mathrm{Fe}^{3+}$-doped nanostructured $\mathrm{TiO}_{2}$ thin films," Thin Solid Films, vol. 516, no. 15, pp. 4690-4694, 2008.

[10] Q. Ling, J. Sun, and Q. Zhou, "Preparation and characterization of visible-light-driven titania photocatalyst co-doped with boron and nitrogen," Applied Surface Science, vol. 254, no. 10, pp. 3236-3241, 2008.

[11] J. Xu, Y. Ao, D. Fu, and C. Yuan, "Synthesis of $\mathrm{Bi}_{2} \mathrm{O}_{3}-\mathrm{TiO}_{2}$ composite film with high-photocatalytic activity under sunlight irradiation," Applied Surface Science, vol. 255, no. 5, pp. 23652369, 2008 .

[12] K. Lv, H. Zuo, J. Sun et al., "(Bi, C and N) codoped $\mathrm{TiO}_{2}$ nanoparticles," Journal of Hazardous Materials, vol. 161, no. 1 , pp. 396-401, 2009.

[13] S. D. Sharma, D. Singh, K. K. Saini et al., "Sol-gel-derived superhydrophilic nickel doped $\mathrm{TiO}_{2}$ film as active photo-catalyst," Applied Catalysis A, vol. 314, no. 1, pp. 40-46, 2006.

[14] Y. Li, G. Ma, S. Peng, G. Lu, and S. Li, "Boron and nitrogen codoped titania with enhanced visible-light photocatalytic activity for hydrogen evolution," Applied Surface Science, vol. 254, no. 21, pp. 6831-6836, 2008.
[15] X. Z. Bu, G. K. Zhang, Y. Y. Gao, and Y. Q. Yang, "Preparation and photocatalytic properties of visible light responsive $\mathrm{N}$-doped $\mathrm{TiO}_{2} /$ rectorite composites," Microporous and Mesoporous Materials, vol. 136, no. 1-3, pp. 132-137, 2010.

[16] L. Sikong, M. Masae, K. Kooptarnond, W. Taweepreda, and F. Saito, "Improvement of hydrophilic property of rubber dipping former surface with $\mathrm{Ni} / \mathrm{B} / \mathrm{TiO}_{2}$ nano-composite film," Applied Surface Science, vol. 258, no. 10, pp. 4436-4443, 2012.

[17] B. Xin, D. Ding, Y. Gao, X. Jin, H. Fu, and P. Wang, "Preparation of nanocrystalline $\mathrm{Sn}-\mathrm{TiO}_{2}-\mathrm{X}$ via a rapid and simple stannous chemical reducing route," Applied Surface Science, vol. 255, no. 11, pp. 5896-5901, 2009.

[18] L. Zhang, F. Lv, W. Zhang et al., "Photo degradation of methyl orange by attapulgite- $\mathrm{SnO}_{2}-\mathrm{TiO}_{2}$ nanocomposites," Journal of Hazardous Materials, vol. 171, no. 1-3, pp. 294-300, 2009.

[19] X. Cheng, X. Yu, Z. Xing, and J. Wan, "Enhanced photocatalytic activity of nitrogen doped $\mathrm{TiO}_{2}$ anatase nano-particle under simulated sunlight irradiation," in Proceedings of the International Conference on Future Energy, Environment, and Materials (FEEM '12), vol. 16, pp. 598-605, April 2012.

[20] A. J. Zaleska, J. W. Sobczak, E. Grabowska, and J. Hupka, "Preparation and photocatalytic activity of boron-modified $\mathrm{TiO}_{2}$ under UV and visible light," Applied Catalysis B, vol. 78, no. 1-2, pp. 92-100, 2008.

[21] X. Zhang and Q. Liu, "Preparation and characterization of titania photocatalyst co-doped with boron, nickel, and cerium," Materials Letters, vol. 62, no. 17-18, pp. 2589-2592, 2008.

[22] J. Yang, H. Bai, Q. Jiang, and J. Lian, "Visible-light photocatalysis in nitrogen-carbon-doped $\mathrm{TiO}_{2}$ films obtained by heating $\mathrm{TiO}_{2}$ gel-film in an ionized $\mathrm{N}_{2}$ gas," Thin Solid Films, vol. 516, no. 8 , pp. 1736-1742, 2008.

[23] M. Ramani, S. Ponnusamy, and C. Muthamizhchelvan, "From zinc oxidenanoparticles to microflowers: a study of growth kinetics and biocidal activity," Materials Science Engineering C, vol. 32, no. 8, pp. 2381-2389, 2012.

[24] G. Rajakumara, A. Abdul Rahumana, S. Mohana Roopanb et al., "Fungus-mediatedbiosynthesis and characterization of $\mathrm{TiO}_{2}$ nanoparticles and their activity againstpathogenic bacteria," Spectrochimica Acta A, vol. 91, pp. 23-29, 2012.

[25] X. Wang and W. Gong, "Bactericidal and photocatalytic activity of $\mathrm{Fe}^{3+}-\mathrm{TiO}_{2}$ thin films prepared by the sol-gel method," Journal Wuhan University of Technology, vol. 23, no. 2, pp. 155-158, 2008.

[26] L. Sikong, B. Kongreong, D. Kantachote, and W. Sutthisripok, "Inactivation of Salmonella typhi using $\mathrm{Fe}^{3+}$ doped $\mathrm{TiO}_{2} / 3 \mathrm{SnO}_{2}$ photocatalytic powders and films," Journal of Nano Research, vol. 12, pp. 89-97, 2010. 

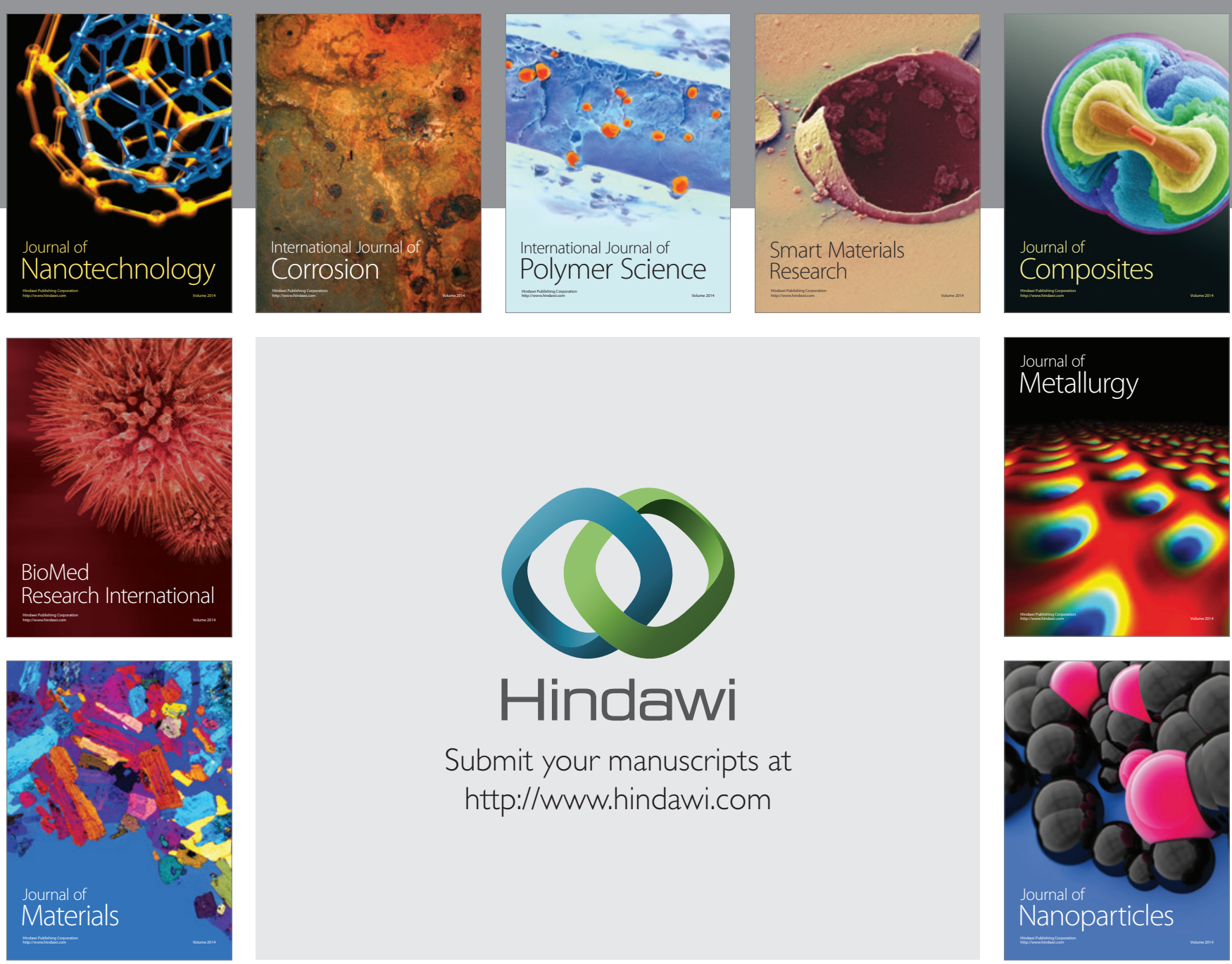

Submit your manuscripts at http://www.hindawi.com
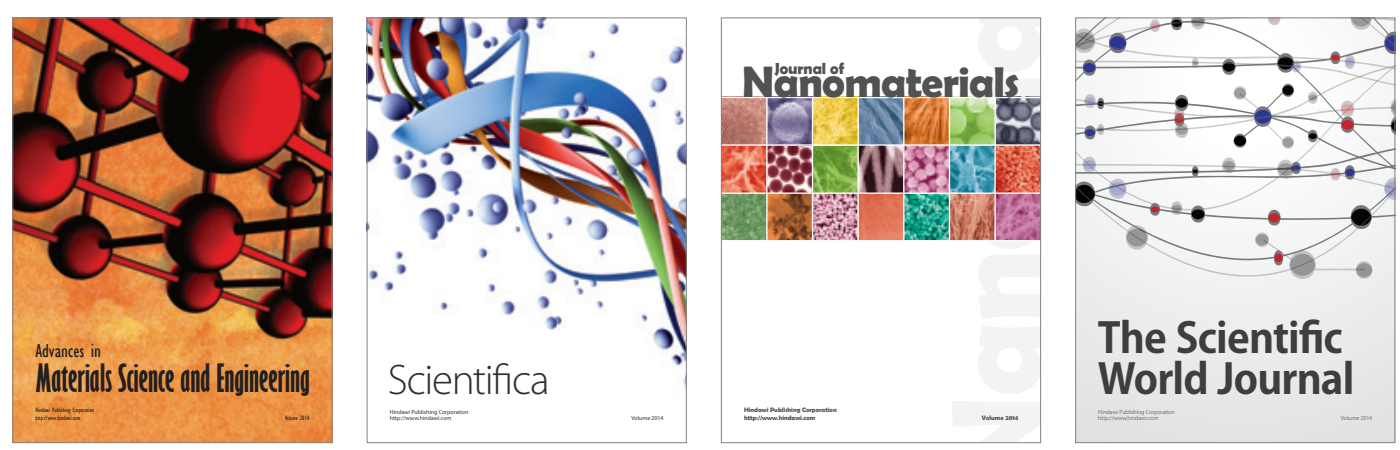

\section{The Scientific World Journal}
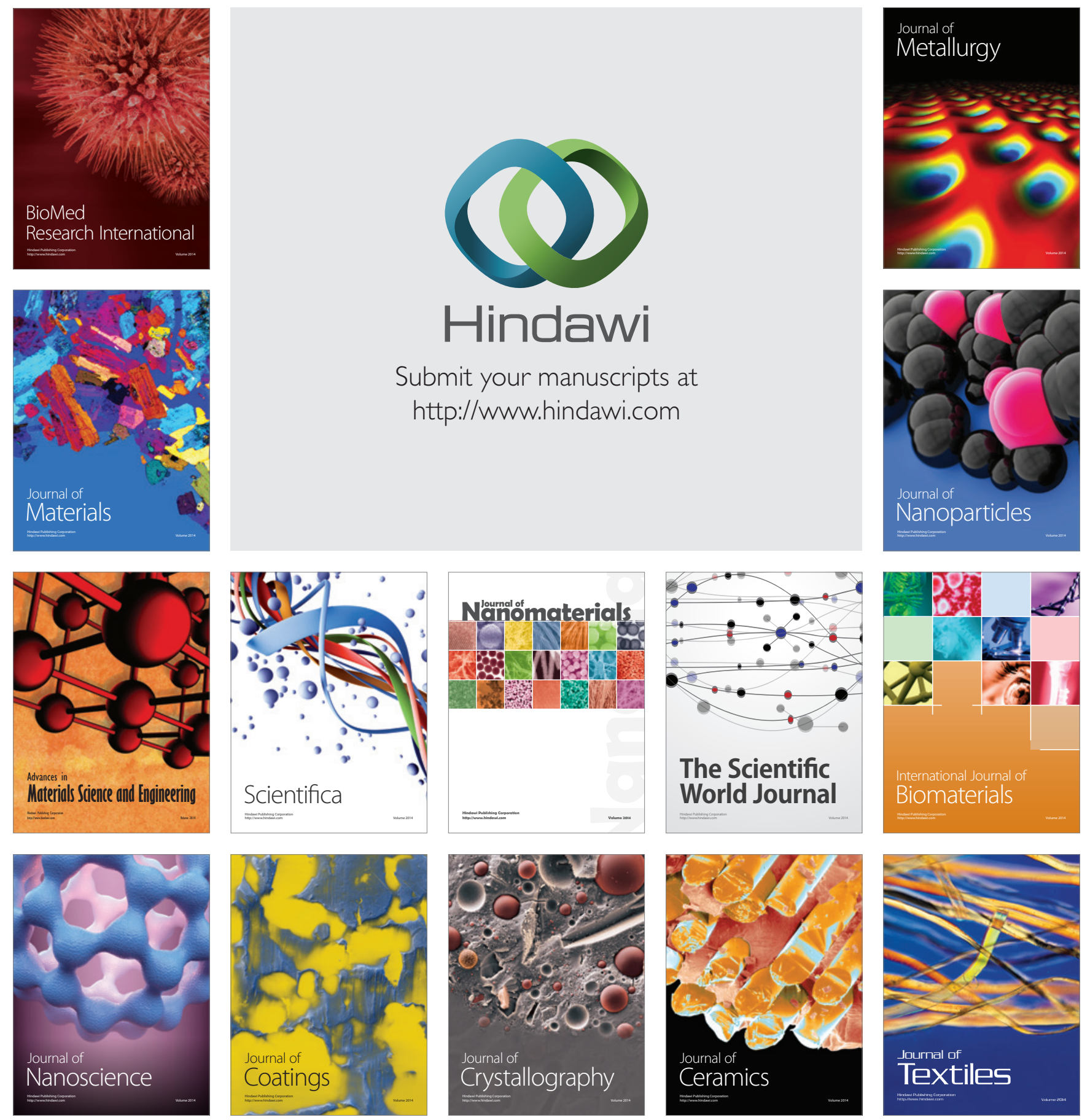